\title{
High levels of circulating triiodothyronine induce plasma cell differentiation
}

\author{
Flavia Fonseca Bloise ${ }^{1,2}$, Felipe Leite de Oliveira', Alberto Félix Nobrega ${ }^{3}$, \\ Rita Vasconcellos ${ }^{5}$, Aline Cordeiro ${ }^{2}$, Luciana Souza de Paiva ${ }^{4,5}$, Dennis D Taub ${ }^{6}$, \\ Radovan Borojevic ${ }^{1}$, Carmen Cabanelas Pazos-Moura ${ }^{2}$ and Valéria de Mello-Coelho' \\ ${ }^{1}$ Laboratory of Immunophysiology, Institute of Biomedical Sciences, ${ }^{2}$ Institute of Biophysics Carlos Chagas Filho, \\ ${ }^{3}$ Institute of Microbiology Paulo de Góes and ${ }^{4}$ Institute of Medical Biochemistry, Federal University of Rio de \\ Janeiro/UFRJ, Health Sciences Building, Av. Carlos Chagas Filho 373, Rio de Janeiro 21941-902, Brazil \\ ${ }^{5}$ Institute of Biology, Fluminense Federal University, Niterói, Rio de Janeiro 24210-150, Brazil \\ ${ }^{6}$ National Institute on Aging, NIH, 251 Bayview Boulevard, Baltimore, Maryland 21224, USA
}

Correspondence should be addressed to $\mathrm{V}$ de Mello-Coelho Email coelhova@histo.ufrj.br

\begin{abstract}
The effects of hyperthyroidism on B-cell physiology are still poorly known. In this study, we evaluated the influence of high-circulating levels of 3,5,3'-triiodothyronine $\left(T_{3}\right)$ on bone marrow, blood, and spleen B-cell subsets, more specifically on B-cell differentiation into plasma cells, in C57BL/6 mice receiving daily injections of $\mathrm{T}_{3}$ for 14 days. As analyzed by flow cytometry, $T_{3}$-treated mice exhibited increased frequencies of pre-B and immature B-cells and decreased percentages of mature B-cells in the bone marrow, accompanied by an increased frequency of blood B-cells, splenic newly formed B-cells, and total CD19 ${ }^{+}$B-cells. $\mathrm{T}_{3}$ administration also promoted an increase in the size and cellularity of the spleen as well as in the white pulp areas of the organ, as evidenced by histological analyses. In addition, a decreased frequency of splenic $\mathrm{B}_{2} 20^{+}$cells correlating with an increased percentage of $\mathrm{CD}_{138^{+}}$plasma cells was observed in the spleen and bone marrow of $\mathrm{T}_{3}$-treated mice. Using enzyme-linked immunospot assay, an increased number of splenic immunoglobulinsecreting $B$-cells from $\mathrm{T}_{3}$-treated mice was detected ex vivo. Similar results were observed in mice immunized with hen egg lysozyme and aluminum adjuvant alone or together with treatment with $T_{3}$. In conclusion, we provide evidence that high-circulating levels of $T_{3}$ stimulate plasmacytogenesis favoring an increase in plasma cells in the bone marrow, a longlived plasma cell survival niche. These findings indicate that a stimulatory effect on plasma cell differentiation could occur in untreated patients with Graves' disease.
\end{abstract}
Key Words
- hyperthyroidism
- B lymphocyte
- plasma cell
thyroid hormone
- spleen
- bone marrow

Journal of Endocrinology (2014) 220, 305-317

\section{Introduction}

Augmentation of circulating levels of thyroid hormones (THs) can be associated with thyrotoxicosis, a clinical condition resulted from exacerbated $\mathrm{TH}$ action in several tissues (Ioos et al. 2008, Bahn et al. 2011). High levels of thyroxine $\left(\mathrm{T}_{4}\right)$ and/or 3,5,3'-triiodothyronine $\left(\mathrm{T}_{3}\right)$ may result from excessive exogenous $\mathrm{TH}$ intake, such as in overtreated hypothyroid patients, in individuals using weight loss formula, or excessive ingestion of iodine consequent to chronic use of amiodarone, an iodineenriched drug used for treatment of cardiac arrhythmia 
(Ioos et al. 2008, Bahn et al. 2011). Hyperthyroidism is considered to be a form of thyrotoxicosis caused by increased synthesis and secretion of TH by the thyroid gland due to adenoma, multinodular goiter, or Graves' disease. The latter is an autoimmune condition consequent to excessive production of thyroid-stimulating immunoglobulins by plasma cells (Bahn et al. 2011, Hou et al. 2011).

Although it is well established that immunoglobulins secreted by plasma cells are able to stimulate $\mathrm{TH}$ production by the thyroid gland under certain pathological conditions (Ueki et al. 2011), the effects of highcirculating levels of TH on B-cell physiology and plasma cell generation are still poorly understood. The plasma cells originate from B-cells, following their activation and differentiation (Radbruch et al. 2006). In mice and humans, B-cells are continuously produced throughout life from the bone marrow hematopoietic stem cells, which express several membrane molecules on their surfaces. During bone marrow B lymphopoiesis, B lymphocyte precursors undergo a strictly controlled process of differentiation, passing from pre-pro B to pro-B and then to pre-B stages, phenotypically characterized as fractions A-D (Hardy et al. 1991). Progressively, several molecules, including cKit, are downregulated while CD43 expression is also modulated on the surface of these cells (Hardy \& Hayakawa 2001, Ye \& Graf 2007). Subsequently, following the successful rearrangement of the B-cell receptor light chain genes, IgM is expressed on the surface of immature B-cells (Burrows et al. 2002). B-cell maturation further progresses with the expression of IgD and upregulation of IgM and B220. At this stage, B-cells are capable of leaving the bone marrow to enter the blood circulation and peripheral lymphoid organs, such as the spleen, where the final steps of maturation lead to the generation of mature B-cell phenotypes (Allman et al. 2001, Pillai \& Cariappa 2009). In the peripheral lymphoid organs, activated B-cells can further differentiate to generate plasma cells, this is accompanied by the alteration in the expression of several plasma membrane molecules, including B220 and CD138 that are downregulated and upregulated on the cell surface respectively (Justement 2001, Radbruch et al. 2006, Klein \& Dalla-Favera 2007). Once differentiated, the plasma cells either die or migrate to survival niches, such as the bone marrow, where they may survive for long periods of time (Radbruch et al. 2006).

Murine and human splenocytes, including B-cells, express TH receptor (TR), which indicates that TH can act directly on lymphoid cells (Hastings et al. 1997, Shahrara et al. 1999, De Vito et al. 2011). Supporting the hypothesis that TH might regulate B-cell physiology, Klecha et al.
(2006) showed that protein kinase C, a signal transduction molecule involved in lymphocyte activation, is increased or decreased in B-cells from hyperthyroid or hypothyroid mice respectively. Previously, Fabris (1973) demonstrated that thyroidectomy in neonatal or young adult rats decreased the number of peripheral blood lymphocytes and humoral immune response. Moreover, studies using $\mathrm{TR} \alpha$ knockout or hyt/hyt mice, a model for congenital hypothyroidism, showed a decrease in the number of splenic B lymphocytes and in the bone marrow B lymphopoiesis (Foster et al. 1999, Arpin et al. 2000).

In this study, we investigated the effects of highcirculating levels of $\mathrm{T}_{3}$ on the profile of $\mathrm{B}$ lymphocyte subpopulations in the spleen, bone marrow, and blood as well as on plasma cell differentiation and antibody secretion in mice. Our results indicate that high-circulating levels of $\mathrm{T}_{3}$ alter B-cell maturation and induce increased B-cell differentiation into immunoglobulin-secreting plasma cells in vivo.

\section{Materials and methods}

\section{Animals}

Male and female C57BL/6 mice were maintained in a $12 \mathrm{~h}$ light:12 $\mathrm{h}$ darkness photoperiod cycle, at room temperature, with access to water and food ad libitum. Mice were killed in a $\mathrm{CO}_{2}$ chamber. All experiments were done after approval by the Ethical Committee for Animal Use in research of the Federal University of Rio de Janeiro.

\section{In vivo $\mathrm{T}_{3}$ treatment}

Mice received daily s.c. administration of $\mathrm{T}_{3}$ (Sigma) at $5 \mu \mathrm{g} / 10 \mathrm{~g}$ of body weight (BW) for 14 days. The animals received injections of $100 \mu \mathrm{l}$ of $\mathrm{T}_{3}$ sterile solution (previously diluted from the stock solution at $0.5 \mathrm{mg} / \mathrm{ml}$ in sterile saline) according to their BW or of $100 \mu$ lof sterile vehicle solution. The animals were killed one day after the end of the treatment. Blood and tissues were collected for further analyses as described below.

\section{Measurement of serum levels of $\mathrm{T}_{3}, \mathrm{~T}_{4}, \mathrm{TSH}$, and immunoglobulins}

Blood was collected from the mouse trunk immediately after killing and centrifuged at $200 \mathrm{~g}$ at $4{ }^{\circ} \mathrm{C}$ for $5 \mathrm{~min}$. Serum was stored at $-70^{\circ} \mathrm{C}$ until use. Determination of total serum levels of $\mathrm{T}_{3}$ and $\mathrm{T}_{4}$ was done using a commercial kit for RIA with specific antibodies (MP-Biochemical, Solon, OH, USA),

Published by Bioscientifica Ltd 
according to the manufacturers protocol. Serum TSH concentration was measured by RIA, employing reagents supplied by the National Hormone and Peptide Program/ National Institutes for Health (NHPP/NIH, Torrance, CA, USA), as described previously (Oliveira et al. 2006).

To determine immunoglobulin serum levels, sandwich ELISA was carried out in flat-bottomed polystyrene 96-well-plates (Corning/Costar, Corning, NY, USA) coated with goat anti-mouse IgG antibodies (Southern Biotechnology, Birmingham, AL, USA). Plates coated with hen egg lysozyme (HEL; Sigma) were used to measure serum levels of HEL-specific IgM. Plates were washed three times with PBS pH 7.4 containing 0.1\% Tween 20 (Vetec, São Paulo, Brazil). Unspecific binding was avoided through blocking with PBS solution containing $1 \%$ gelatin (Merck) at $25^{\circ} \mathrm{C}$ for $2 \mathrm{~h}$ before washing with PBS. Serum diluted in PBS containing 1\% gelatin and 0.1\% Tween 20 was added to the plates and incubated at $4{ }^{\circ} \mathrm{C}$ overnight. The plates were washed and incubated with rabbit antimouse $\mathrm{F}\left(\mathrm{ab}^{\prime}\right) 2$ or IgM conjugated to HRP (Jackson Immune Research, West Grove, PA, USA) at $25^{\circ} \mathrm{C}$ for $2 \mathrm{~h}$. Immunoglobulin isotype control (Southern Biotechnology) was used to generate standard curves. The plates were incubated with 3,3',5,5'-tetramethylbenzidine (TMB; Sigma) and the absorbance was detected using an ELISA plate reader (Bio-Rad) at a wavelength of $650 \mathrm{~nm}$.

\section{Immunization}

Male mice were immunized on day 0 with a single i.p. injection of $100 \mu \mathrm{g}$ of $\mathrm{HEL}$ and $1.5 \mathrm{mg}$ of aluminum hydroxide (Alum; EMS, São Paulo, Brazil) as adjuvant. Animals treated with HEL or saline solution were then treated or not treated with $\mathrm{T}_{3}$, as described previously. Analyses were carried out on the 15th day after hormonal treatment in the four groups of mice: unimmunized (CTR); HEL-Alum immunized (HEL-Alum), unimmunized plus $\mathrm{T}_{3}$-treatment $\left(\mathrm{T}_{3}\right)$; and HEL-Alum immunized plus $\mathrm{T}_{3}$-treatment $\left(\mathrm{T}_{3}+\right.$ HEL-Alum).

\section{Cell isolation, collection of tissues, and histological staining}

Bone marrow cells were obtained by flushing the femurs of the animals with culture medium (RPMI-1640, Sigma) injected through a 21 gauge needle. Spleens were removed and weighed before being smashed on a nylon membrane (Becton Dickinson, San Jose, CA, USA) in a Petri dish with culture medium supplemented with $10 \%$ fetal bovine serum (FBS; Gibco-Life Technology). The cell suspensions were centrifuged for $5 \mathrm{~min}$ at $200 \boldsymbol{g}$ and the cell pellet was resuspended in $3 \mathrm{ml}$ of saline or culture medium supplemented with $10 \%$ of FBS. Peripheral blood was isolated and samples were centrifuged at $200 \boldsymbol{g}$ at $4{ }^{\circ} \mathrm{C}$ for $5 \mathrm{~min}$ using ammonium chloride-potassium buffer for lysis of red blood cells. Peripheral blood cells were collected from the pellet. For histological analyses, spleens were sliced into small pieces and maintained in $4 \%$ formalin overnight. The material was dehydrated in graded ethanol baths for $15 \mathrm{~min}$, washed in xylene three times for $15 \mathrm{~min}$ before paraffin embedding. Paraffin blocks with spleens were sliced and $5 \mu \mathrm{m}$ tissue sections were stained with Harrison's hematoxylin and eosin (Sigma).

\section{Flow cytometry}

The cell suspensions obtained from bone marrow, spleen, or blood of mice were submitted to flow cytometry analyses. A total of $10^{6}$ viable cells was washed with PBS supplemented with 5\% FBS. Bone marrow cells were incubated with Fc receptor blocker (clone 2.4G2) for $10 \mathrm{~min}$ for non-specific binding of primary antibodies. The cells were stained with combinations of MABs specific for anti-mouse B220 (clone RA3-6B2) conjugated to PE or PerCP, -TCR-FITC (clone H57-597), -GR1-PercP (clone RB6-8C5), -CD138-PE (clone 281-2), -CD19-PE (clone 1D3), -CD21-FITC (clone 7G6), -CD23-PE (clone B3B4), IgM-FITC (clone II/41), -CD43-PE (clone S7), and -c-KitAPC (clone 2B8). All antibodies were obtained from BD Pharmingen (San Jose, CA, USA). The cells were incubated in the dark at $4{ }^{\circ} \mathrm{C}$ for $30 \mathrm{~min}$, washed and resuspended in PBS supplemented with FBS (5\%). A total of 10000 events were acquired in the forward scatter/side scatter (FSC/SSC) gate designed for the cell population of interest, using an Accuri C6, FACScan, or FACScalibur Cytometer (Becton Dickinson, USA). Data acquired were analyzed using C Flow (Becton Dickinson) or Win MDI 2.9 Software (The Scripps Institute, La Jolla, CA, USA). The total cellularity of the organ was quantified using a hemocytometer. The percentage of the cell population of interest in the organ was obtained following FACS analysis. The absolute number of each cell population was calculated considering the respective percentage in the organ relative to the total cellularity of the organ for each animal.

\section{Enzyme-linked immunospot assay to enumerate antibody-secreting plasma cells ex vivo}

Splenocytes obtained from unimmunized or HEL-Alum immunized mice treated or not treated with $\mathrm{T}_{3}$ were used.

Published by Bioscientifica Ltd. 
Flat-bottomed polystyrene 96-well-plates (Corning/ Costar) were coated with goat anti-mouse IgM antibody (Southern Biotechnology) at $4{ }^{\circ} \mathrm{C}$ overnight. The plates were washed with PBS (pH 7.4) and blocked for $1 \mathrm{~h}$ with PBS containing 1\% gelatin (Sigma). Serially diluted cell suspension (a total of $2 \times 10^{4}$ cells/well) in RPMI with $5 \%$ FBS was incubated for $6 \mathrm{~h}$ at $37^{\circ} \mathrm{C}$ in an atmosphere of $5 \%$ $\mathrm{CO}_{2}$. The plates were washed with PBS and $0.1 \%$ Tween 20 before incubation with goat anti-mouse IgM conjugated to alkaline phosphatase (Southern Biotechnology) at $4{ }^{\circ} \mathrm{C}$ overnight. Following washing, spots generated by specific binding of secreted immunoglobulins were revealed with TMB (Sigma). The plates were washed in water and dried at room temperature. The numbers of spots were quantified by counting, using an Olympus CKX41SF inverted microscope. The numbers of counted spots were multiplied by the dilution factor indicating the number of immunoglobulin-secreting cells in the well. For each animal, the total cellularity of the spleen was considered to quantify the total number of immunoglobulin-secreting splenic plasma cells.

\section{Statistical analyses}

Statistical analyses were carried out using GraphPad Prism, version 5 (Prism Software, La Jolla, CA, USA). The unpaired Student's $t$-test was used for the analyses of immunoglobulin and TH serum levels assays, ex vivo enzyme-linked immunospot (ELISpot) assay, ELISA, and flow cytometry experiments. A non-parametric non-paired $t$-test (MannWhitney) was used for TSH statistical analysis. A two-way ANOVA test was used to analyze differences between males and females. $P$ values of 0.05 or less were considered statistically significant.

\section{Results}

\section{Serum $T_{3}, T_{4}$, and TSH in $T_{3}$-treated mice}

As $T_{3}$ is three to four times more potent than $T_{4}$ (Walfish 1976), the induction of thyrotoxicosis using exogenous administration of $\mathrm{T}_{3}$ instead of $\mathrm{T}_{4}$ has the advantage of providing the immune cells with the most biologically active $\mathrm{TH}$. Indeed, the choice for $\mathrm{T}_{3}$ administration in our study avoids the need for the conversion of intracellular $\mathrm{T}_{4}$ to $\mathrm{T}_{3}$ that is a required for most of $\mathrm{T}_{4}$ actions and occurs by enzymatic deiodination, for which the activity and regulation is not clear for B-cells (Bianco 2011).

Male and female mice treated for 14 days with $\mathrm{T}_{3}$ (50 $\mathrm{g} / 10 \mathrm{~g}$ per day) exhibited a threefold to fourfold
Table 1 Serum levels of $T_{3}, T_{4}$, and TSH in mice with highcirculating levels of $\mathrm{T}_{3}$.

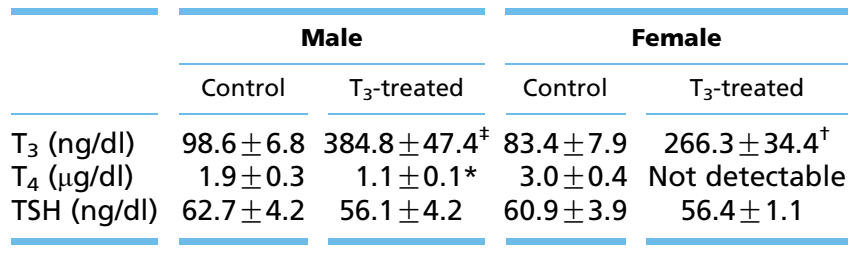

Differences in thyroid hormone $(\mathrm{TH})$ circulating levels in mice treated or not with $T_{3}$ were analyzed by unpaired Student's $t$-test. Non-parametric nonpaired $t$-test (Mann-Whitney) for TSH statistic analysis and unpaired $t$-test was used for TH serum levels. Values are shown as mean \pm s.E.M. For analyses of $\mathrm{T}_{3}$ RIA $n=9$ for control (CTR) and $\mathrm{T}_{3}$-treated males, $n=7$ for CTR and $n=9$ for $T_{3}$-treated females; $T_{4}$ RIA, $n=14$ for CTR and $T_{3}$-treated males, $n=7$ for CTR, and $n=6$ for T3-treated females; and TSH, $n=6$ for CTR and $\mathrm{T}_{3}$-treated males, $n=4$ for CTR and $\mathrm{T}_{3}$-treated females. ${ }^{*} P<0.05$, ${ }^{+} P<0.0005$, and ${ }^{\ddagger} P<0.0001$.

increase in serum $T_{3}$, as evaluated by RIA. $T_{3}$ treatment resulted in a significant decrease in serum $\mathrm{T}_{4}$ and a trend towards decrease serum TSH (Table 1).

\section{Changes in the spleen weight, cellularity, and morphology in mice with high-circulating levels of $T_{3}$}

We investigated the effects of excess $T_{3}$ in the spleen, one of the peripheral lymphoid organs where B-cells reside and differentiate into plasma cells. High-circulating levels of $\mathrm{T}_{3}$ promoted a significant increase in the spleen weight of male and female mice (Fig. 1A and B). It was also possible to identify an increase of 80.3 and $50.4 \%$ in the weight of the spleens relative to respective BWs, in male and female $\mathrm{T}_{3}$-treated mice (Fig. 1C and D). The effect of excess $\mathrm{T}_{3}$ on the spleen weight or on the ratio between the spleen weight and the corresponding BW was more significant in male than female mice $(P<0.05)$. Moreover, $\mathrm{T}_{3}$ promoted an enhancement in the absolute numbers of splenocytes in these animals and no significant difference was found between male and female mice (Fig. 1E and F). This effect was related to an increase in the white pulp compartment of the spleens of mice that received injections of $\mathrm{T}_{3}$, as analyzed by hematoxylin and eosin staining (Fig. 1G and $\mathrm{H}$ ). Interestingly, in some spleen tissue sections of $\mathrm{T}_{3}$-treated mice, the white pulp areas, normally separated, were fused.

Influences of high-circulating levels of $T_{3}$ on the profile of splenic B lymphocyte subpopulations

To investigate the effects of high-circulating levels of $T_{3}$ on the absolute numbers and frequencies of splenic $\mathrm{B}$

Published by Bioscientifica Ltd. 

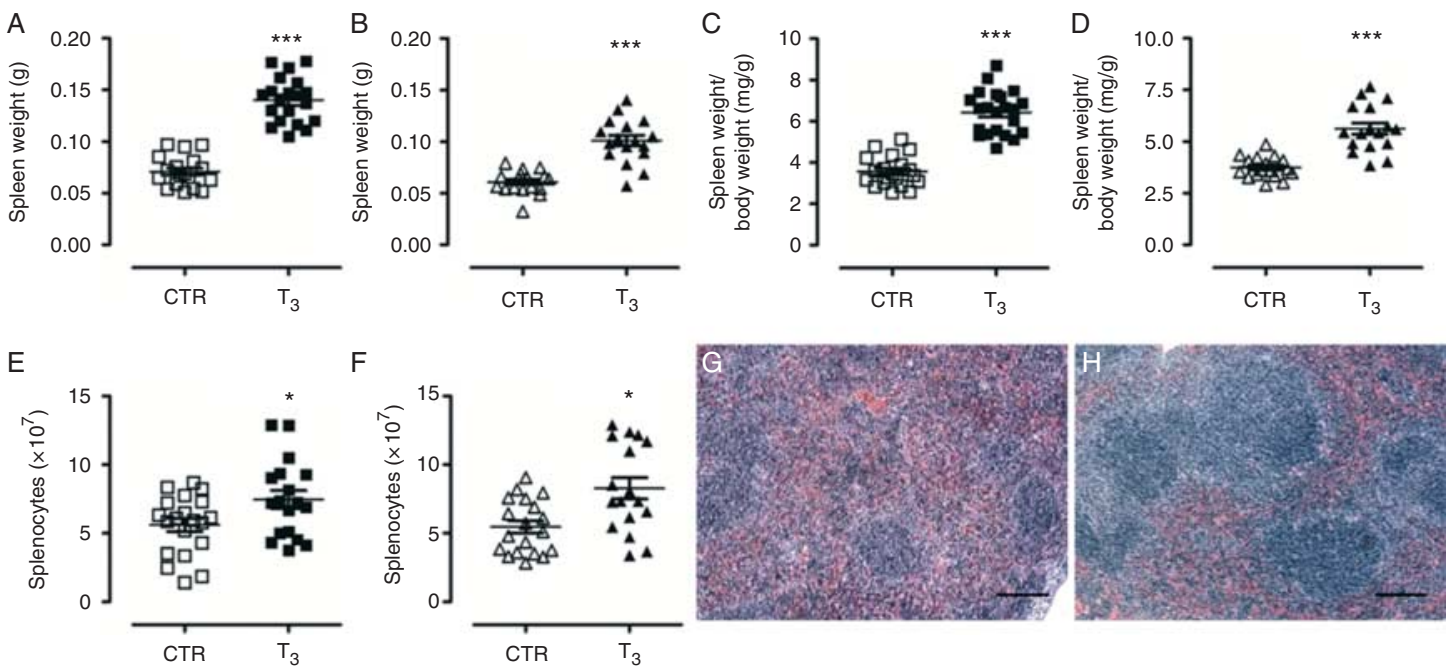

Figure 1

In vivo $\mathrm{T}_{3}$ treatment increases the weight, cellularity, and lymphoid area of the spleen in male and female mice. Spleens were isolated from 5-6-weekold mice after treatment with $\mathrm{T}_{3}$ or saline (CTR) for 14 days. Male groups are indicated by squares $(A, C$ and $E$ ) and female groups by triangles

( $B, D$ and $F$ ). ( $A$ and $B$ ) Spleen weight; ( $C$ and $D$ ) spleen weight corrected per

lymphocytes, we carried out flow cytometry analyses. Our results showed that excess $\mathrm{T}_{3}$ promoted only a trend towards an increase in the absolute number of $\mathrm{B} 220^{+} \mathrm{B}$ cells in the spleen of male (control, $5.2 \pm 0.7 \times 10^{7}$ cells; T -treated, $5.7 \pm 1.2 \times 10^{7}$ cells; $\left.P=0.16\right)$ and female (control, $4.0 \pm 0.4 \times 10^{7}$ cells; $T_{3}$-treated, $5.0 \pm 0.6 \times 10^{7}$ cells, $P=0.7$ ) animals. On the other hand, the hormonal treatment reduced significantly the frequency of $\mathrm{B} 220^{+} \mathrm{B}$ lymphocytes in the spleen of male (19.1\%) and female mice (8.0\%) (Fig. 2A, B and C). In addition, we found a decrease in B220 expression per cell in splenic cells of $\mathrm{T}_{3}$-treated male (40.9\% less than control) and female mice (27.9\% less than control) (Fig. 2D and E). Interestingly, we have found more pronounced effects of high-circulating levels of $\mathrm{T}_{3}$ reducing the frequency of splenic $\mathrm{B} 220^{+}$cells in male than female mice $(P<0.005)$.

Although B220 is mainly expressed in B-cells, it can be also found in some activated $\mathrm{T}$ lymphocytes and myeloid granulocytic cells (Renno et al. 1998, Nakano et al. 2001). To evaluate whether the decreased levels of B220 in splenic cells could be reflecting a possible $T_{3}$ modulation of the frequency of these cell populations in the spleen, we carried out FACS analysis using B220 with TCR or GR1 cell markers in $\mathrm{T}_{3}$-treated male mice. We found that the in vivo treatment with $\mathrm{T}_{3}$ reduced frequency of B220 in splenic $\mathrm{TCR}^{+} \mathrm{T}$ cells by $2 \%$ (control, $5.8 \pm 0.6 \%, n=3 ; \mathrm{T}_{3}$-treated, $3.8 \pm 0.3 \%, n=3 ; P<0.05)$ while the percentage of splenic $\mathrm{B} 220^{+} \mathrm{Gr}^{+}$cells did not change significantly between animal weight; and ( $E$ and $F$ ) total splenocyte cell numbers. Each symbol represents an animal. Values represent mean \pm S.E.M. $* P<0.05$ and $* * * P<0.001$. (G and $\mathrm{H}$ ) Representative histological photomicrographs of the spleen of control and $\mathrm{T}_{3}$-treated mice respectively. White pulp is stained blue and red pulp is stained dark red. Scale bar: $200 \mu \mathrm{m}$.

control and $\mathrm{T}_{3}$-treated mice (control, $4.8 \pm 0.2 \%, n=3$; $\mathrm{T}_{3}$-treated group, $5.2 \pm 0.3 \%, n=3$ ). On the other hand, the percentages of $\mathrm{B}^{2} 20^{+} \mathrm{TCR}^{-}$cells (control, $56.0 \pm 1.4 \%$, $n=3 ; \mathrm{T}_{3}$-treated, $\left.46.4 \pm 2.9 \%, n=3 ; P<0.05\right)$ significantly decreased by close to $10 \%$ while the percentage of $\mathrm{B}_{220}{ }^{+} \mathrm{GR} 1^{-}$(control, $47.5 \pm 2.6 \%, n=3 ; \mathrm{T}_{3}$-treated, $38.7 \pm 2.5 \%, n=3$ ) showed a trend towards a decrease in the $\mathrm{T}_{3}$-treated group in relation to controls. These results indicate that reduced expression of B220 might occur in the B lymphocyte population.

The in vivo effect of $\mathrm{T}_{3}$ reducing the expression of B220 per cell raised the hypothesis that high-circulating levels of this hormone could be stimulating splenic B-cells to differentiate to plasma cells. We next analyzed the effects of excess $T_{3}$ on the expression of CD19, which is another marker of B-cells that is down-modulated in fully differentiated plasma cells and, compared with B220, maintains its expression longer (Kallies et al. 2004, Fairfax et al. 2008). We found that the frequency and absolute numbers of splenic CD19 ${ }^{+} \mathrm{B}$-cells were increased in $\mathrm{T}_{3}$-treated male mice (Fig. 3A, B and $\mathrm{C}$ ).

To better elucidate these possible contradictory effects of in vivo $\mathrm{T}_{3}$ treatment on B220 and CD19 expression on splenic B-cells, we also evaluated the B lymphocyte subpopulations in the spleen of male mice, using the cell markers CD21, CD23, and B220, which allow the identification of newly formed (NF, B220 ${ }^{+} \mathrm{CD} 21^{-} \mathrm{CD} 23^{-}$), marginal zone $\left(\mathrm{MZ}, \mathrm{B} 220^{+} \mathrm{CD} 21^{+} \mathrm{CD} 23^{-}\right)$, and follicular

Published by Bioscientifica Ltd. 

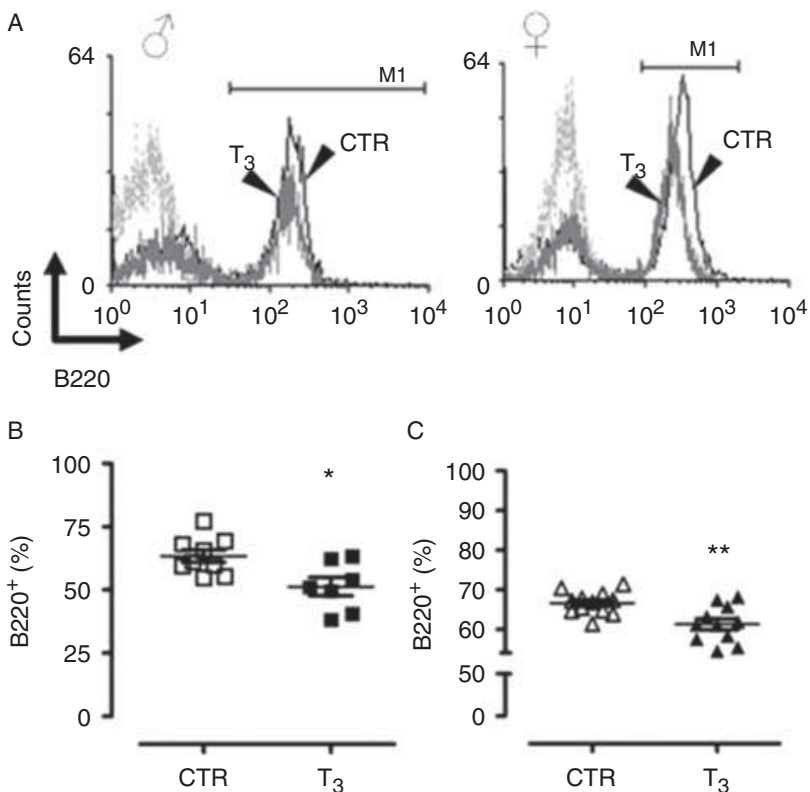

C

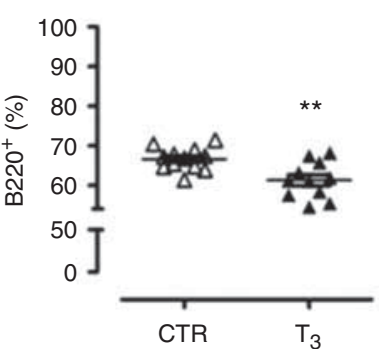

D

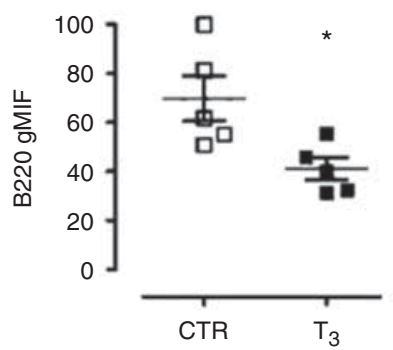

E

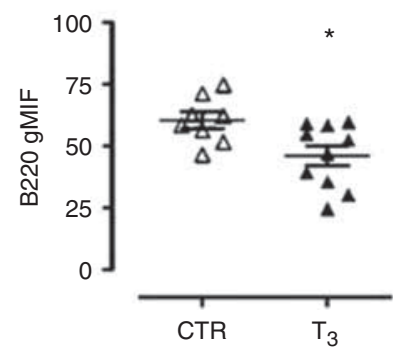

Figure 2

High-circulating levels of $T_{3}$ promote downregulation of B220 expression on splenic cells of male and female mice. Spleens were isolated from 5-6-week-old male or female mice after treatment with $T_{3}$ or saline for 14 days. Isolated splenocytes were submitted to flow cytometry using rat anti-mouse B220-PE. (A) Representative graphs for splenocytes stained for B220. Light gray lines indicate negative controls; arrowheads indicate saline (black lines); or $\mathrm{T}_{3}$-treated animals (dark gray lines). (B and C) Percentage of $\mathrm{B}_{220^{+}}$splenocytes. (D and E) Geometric mean of fluorescence intensity (gMIF) of B220 expression on the surface of splenic cells. Male and female mice are indicated by square and triangle symbols respectively. Each symbol represents an animal. Values represent mean \pm s.E.M. ${ }^{*} P<0.05$ and $* * P<0.005$

(FO, B220 ${ }^{+} \mathrm{CD} 21^{+} \mathrm{CD} 23^{+}$) B-cells (Nijnik et al. 2009, Su et al. 2011; Fig. 3). Although a significant increase in NF B-cells (22\%) was detected in the spleen of $\mathrm{T}_{3}$-treated mice, the percentages of MZ and FO B-cells were significantly decreased (21.4 and 11.8\% respectively; Fig. 3D and E). In addition, the analysis of absolute numbers of these B-cell subpopulations revealed that NF B-cells were significantly increased $(117 \%)$ in the spleen of mice under the influence of excess $\mathrm{T}_{3}$ (Fig. 3C). On the other hand, the numbers of splenic MZ and FO B-cells showed only a slight trend to increase in these mice (Fig. 3F). The increase of NF B-cells in the spleen led us to question whether excess $T_{3}$ in the circulation could be regulating bone marrow B-cell differentiation and emigration to the periphery.

\section{High-circulating levels of $T_{3}$ regulate the frequencies of bone marrow B-cell progenitors and peripheral blood B lymphocytes}

Analyzing the influence of high-circulating levels of $T_{3}$ on bone marrow B-cell progenitors by flow cytometry, we did not find significant changes in the pre-pro $B$ $\left(\mathrm{cKit}^{-/ \mathrm{lo}} \mathrm{IgM}^{-} \mathrm{B}_{220}{ }^{+} \mathrm{CD} 43^{+}\right.$) and pro-B ( $\mathrm{cKit}^{+/ \mathrm{hi}} \mathrm{IgM}^{-}$ $\mathrm{B} 220^{+} \mathrm{CD} 43^{+}$) cell subpopulations (Fig. 4). However, we found an increase of 13.67 and $10.1 \%$ in the mean percentage of bone marrow pre-B-cells (cKit${ }^{-} \mathrm{IgM}^{-} \mathrm{B} 220^{+} \mathrm{CD} 43^{-/ 10}$ ) and immature B-cells (cKit${ }^{-} \mathrm{IgM}^{+} \mathrm{B} 220^{\mathrm{lo}} \mathrm{CD} 3^{-}$) in the groups treated with $\mathrm{T}_{3}$, in relation to their respective controls. Moreover, a reduction of $32.4 \%$ was observed in the mean percentage of bone marrow mature B-cells ( $\mathrm{CKit}^{-} \mathrm{IgM}^{+} \mathrm{B} 22 \mathrm{O}^{\mathrm{hi}} \mathrm{CD} 43^{-}$) in the T3-treated group, as compared with control (Fig. 4A and B). No significant change occurred in the absolute numbers of bone marrow pre-pro B- and pro-B-cells (Fig. 4C). We also noticed a significant increase in the absolute numbers of bone marrow pre-B-cells and immature B-cells in the group treated with $\mathrm{T}_{3}$, corresponding to 57.8 and $68.9 \%$ respectively. However, the absolute number of bone marrow mature B-cells did not change between control and $\mathrm{T}_{3}$-treated mice (Fig. 4C). Because mature B-cells are capable of emigrating from the bone marrow to the blood circulation and peripheral lymphoid organs, we decided to investigate the profile of B-cells in the peripheral blood of mice treated with $\mathrm{T}_{3}$. Interestingly, we found an increase of $8.2 \%$ in the percentage of $\mathrm{B} 220^{+} \mathrm{B}$ cells in the peripheral blood of $\mathrm{T}_{3}$-treated mice (Fig. 4D and $\mathrm{E}$ ).

\section{Plasma cells increase in the spleen and bone marrow of $\mathrm{T}_{3}$-treated mice}

Our data showing a decrease in B220 expression on splenic cells after $\mathrm{T}_{3}$ treatment (Fig. 2B and C) led us to evaluate whether the in vivo $\mathrm{T}_{3}$ treatment could stimulate the expression of CD138, a surface marker for plasma cells, on splenic cells. We found an increase of $\sim 30 \%$ in the percentage of $\mathrm{CD} 138^{+}$plasma cells in the spleen of $\mathrm{T}_{3}$-treated mice, in relation to control (Fig. $5 \mathrm{~A}$ and $\mathrm{B}$ ). The absolute number of $\mathrm{CD} 138^{+}$splenic plasma cells numbers also increased when compared with control animals (Fig. 5C). We could identify small $\left(\mathrm{FSC}^{\mathrm{lo}} \mathrm{CD} 138^{+}\right)$and

Published by Bioscientifica Ltd. 
A

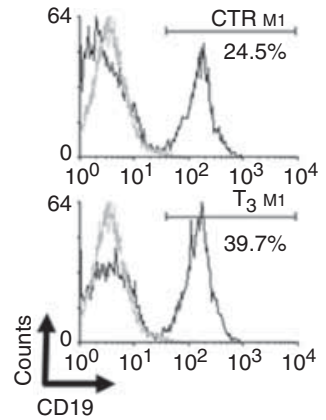

D

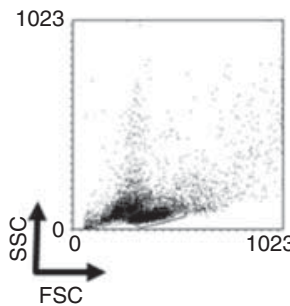

B

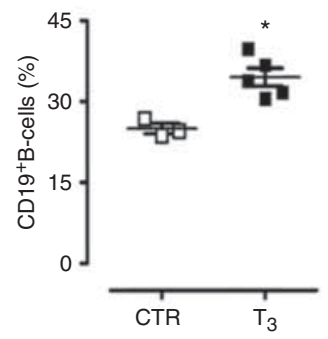

C
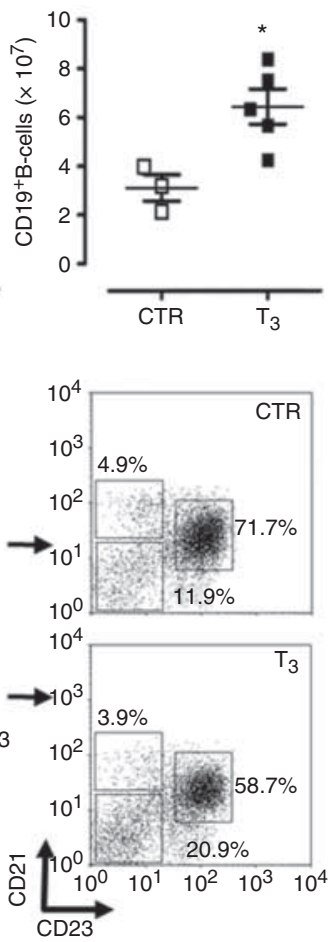

$\mathrm{E}$

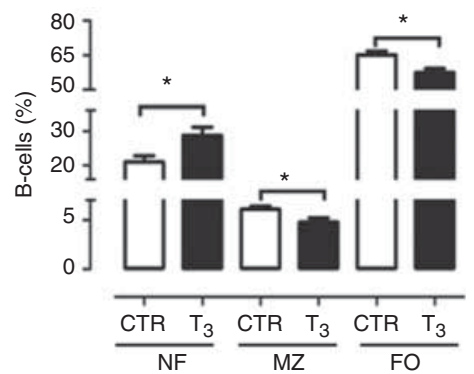

$\mathrm{F}$

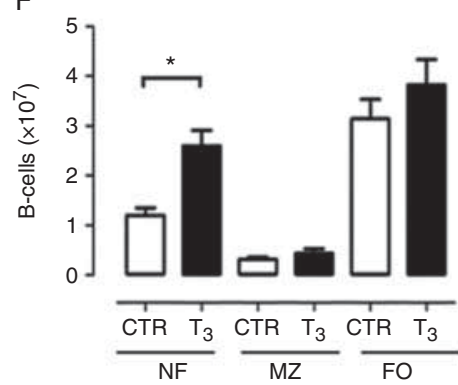

\section{Figure 3}

Excess $T_{3}$ in circulation leads to an increase in NF B-cells in the spleen. Splenocytes isolated from 5-6-week-old male mice after treatment with $T_{3}$ or saline for 14 days were submitted to flow cytometry analysis using the following rat anti-mouse antibodies: anti-CD19-PE, anti-B220-PerCP, antiCD21-FITC, and anti-CD23-PE. (A) Graphs showing CD19 expression in splenic lymphocyte-gated populations of control (CTR) and $\mathrm{T}_{3}$-treated mice $\left(T_{3}\right)$. (B) Frequencies and $(C)$ absolute numbers of $C D 19^{+} B$-cell population. (D) Left panel represents gated lymphocytes in the SSC/FSC dot plot; middle

large (FSC ${ }^{\text {hi }} \mathrm{CD} 138^{+}$) plasma cells in the spleens of these mice (Fig. 5A). An increase of $42 \%$ was noticed in the small plasma cells of $\mathrm{T}_{3}$-treated mice in relation to controls. On the other hand, only a trend towards an increase in the percentage of large plasma cells was observed in the spleen of $\mathrm{T}_{3}$-treated mice. When we analyzed the absolute numbers of small and large splenic plasma cells in the $\mathrm{T}_{3}$-treated and control groups, only the small plasma cells were significantly increased after treatment with $\mathrm{T}_{3}$ (Fig. 5B and C).

Based on the knowledge that plasma cells once differentiated are able to migrate from the spleen to long-lived plasma cell niches, we investigated the possible influence of $T_{3}$ treatment on the frequency and absolute number of plasma cells in the bone marrow (Mebius \& Kraal 2005, Radbruch et al. 2006). However, because a bone marrow B-cell progenitor also expresses CD138 (Montecino-Rodriguez et al. 2006), we used an panel shows the gate designed for $\mathrm{B} 220^{+} \mathrm{B}$ lymphocytes in the B220/FSC dot plot; and right panels show representative dot plots for $C D 21 / C D 23$ expression on $\mathrm{B}^{2} 2 \mathrm{O}^{+}$-gated cells. NF, newly formed B-cells, $\mathrm{B} 220^{+} \mathrm{CD} 21^{-} \mathrm{CD} 23^{-} ; \mathrm{MZ}$, marginal zone B-cells, $\mathrm{B} 220^{+} \mathrm{CD} 21^{+} \mathrm{CD}_{23}{ }^{-}$. $\mathrm{FO}$, follicular B-cells, B220 ${ }^{+} \mathrm{CD} 21^{+} \mathrm{CD}_{23}{ }^{+}$; $\mathrm{CTR}$, saline control; and $\mathrm{T}_{3}$, $\mathrm{T}_{3}$-treated mice. (E) Frequencies of $B 220^{+} \mathrm{B}$ cell population and $(\mathrm{F})$ absolute numbers of NF, MZ, and FO B-cells. Values represent mean \pm S.E.M of at least three animals per group. ${ }^{*} P<0.05$.

anti-CD138 antibody in combination with markers for IgM and cKit in order to identify bone marrow plasma cells $\left(\mathrm{CD} 138^{+} \mathrm{IgM}^{-} \mathrm{cKit}^{-}\right)$. Evaluating the in vivo $\mathrm{T}_{3}$ effect on the percentage of $\mathrm{CD}_{138}{ }^{+} \mathrm{IgM}^{-} \mathrm{cKit}^{-}$plasma cells in the bone marrow (Fig. 5D, E and F), we verified an increase of $41.6 \%$ in relation to control (Fig. 5D and E). Furthermore, the absolute number of plasma cells in the bone marrow survival niche was significantly increased in mice treated with $\mathrm{T}_{3}$ (Fig. 5F).

\section{High-circulating levels of $T_{3}$ increase the number of immunoglobulin-producing plasma cells ex vivo}

Because we found an increase in plasma cell differentiation under the influence of $\mathrm{T}_{3}$ in vivo, we decided to analyze the circulating levels of IgG in male and female mice treated with this hormone, using sera collected throughout the study. No significant changes were detected in the serum 
A
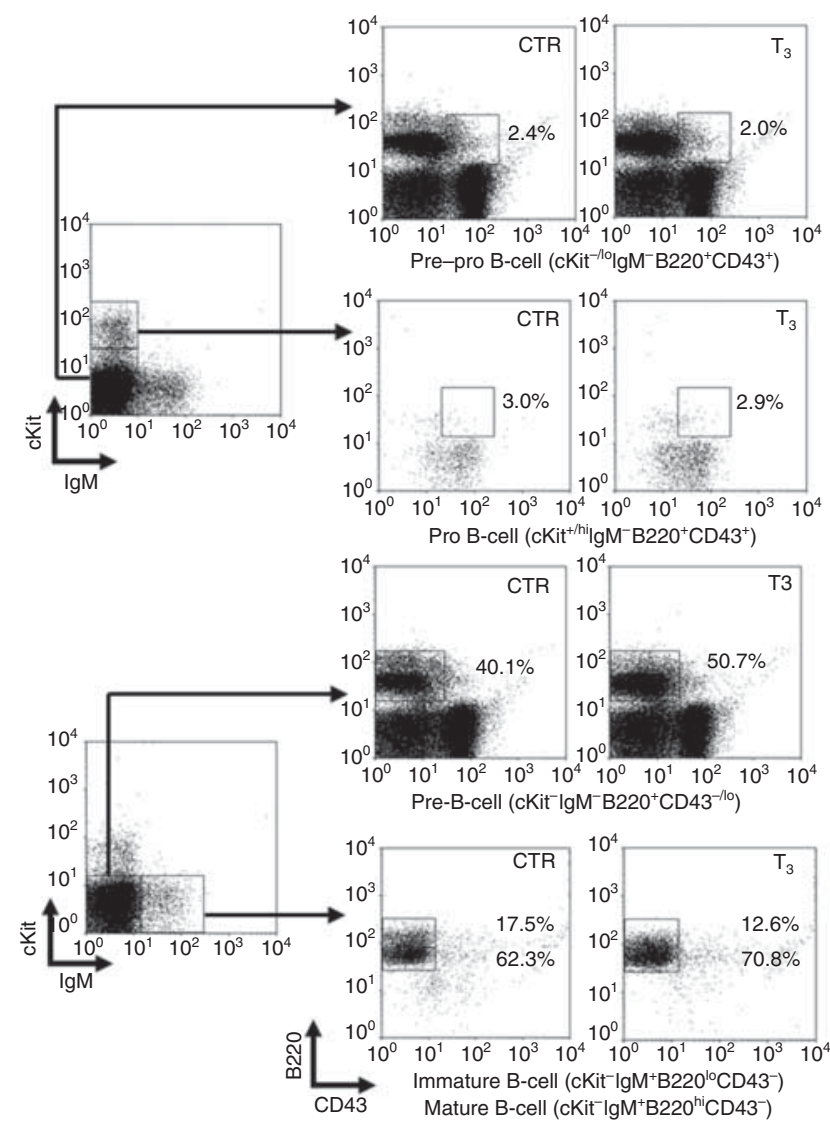

B
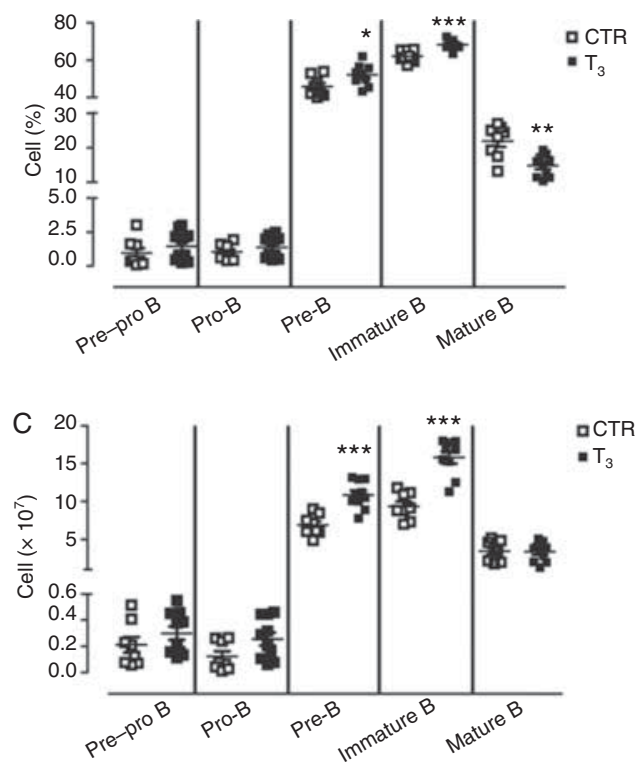

D
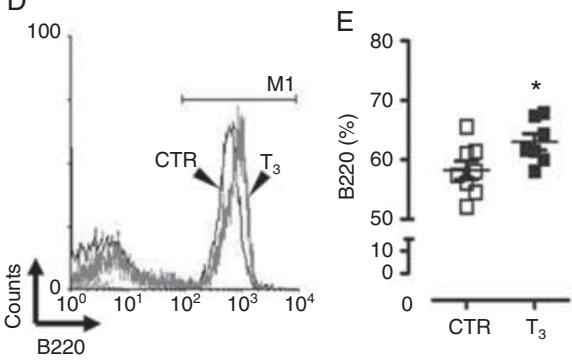

\section{Figure 4}

Effects of excess $T_{3}$ on bone marrow $B$ lymphopoiesis and mature $B$-cells in the peripheral blood. (A, B and C) Bone marrow cells or ( $D$ and $E$ ) peripheral blood lymphocytes were isolated from 5-6-week-old male mice after treatment with $\mathrm{T}_{3}$ or saline (CTR) for 14 days and submitted to flow cytometry analyses. (A) Dot plots represent bone marrow cells stained with anti-CKit-APC, anti-IgM-FITC, anti-B220-PerCP, and anti-CD43-PE antibodies. Arrows indicate $\mathrm{cKit}^{+} \mathrm{IgM}^{-}, \mathrm{cKit}^{-1 \mathrm{lo}} \mathrm{IgM}^{-}, \mathrm{cKit}^{-} \mathrm{IgM}^{-}$, or $\mathrm{cKit}^{-} \mathrm{IgM}^{+}$-gated populations for further analysis based on B220/CD43 expression to characterize distinct stages of bone marrow B-cell

levels of IgG in male (control, $2582 \pm 437.4 \mu \mathrm{g} / \mathrm{ml}, n=15$; T -treated, $2336 \pm 550.8 \mu \mathrm{g} / \mathrm{ml}, n=11 ; P=0.7)$ and female (control, $1937 \pm 493.4 \mu \mathrm{g} / \mathrm{ml}, \quad n=9 ; \mathrm{T}_{3}$-treated, $2161 \pm$ $486.0 \mu \mathrm{g} / \mathrm{ml}, n=11 ; P=0.7)$ animals. These data indicated that the systemic levels of IgG did not alter after 14 days of $\mathrm{T}_{3}$ treatment.

Next, we investigated whether splenic plasma cells isolated from $\mathrm{T}_{3}$-treated mice were able to secrete immunoglobulins (Fig. 6). We verified a significant increase in the number of total ex vivo IgM-secreting plasma cells in the spleens from $\mathrm{T}_{3}$-treated mice (Fig. 6), indicating that $\mathrm{CD} 138^{+}$splenocytes induced to differentiate under the influence of $\mathrm{T}_{3}$ are functional plasma cells. We also differentiation, for which phenotypes are indicated in the figure as prepro $B$, pro-B, pre-B, immature $B$, and mature B-cell subsets. (B) Frequencies and $(C)$ absolute cell numbers of differentiating $B$-cells in the bone marrow. (D) Representative histogram of peripheral blood lymphocytes stained with anti-mouse B220-PE antibody. Arrowheads indicate lines corresponding to saline (CTR) or $\mathrm{T}_{3}$-treated mice. (E) Relative numbers of peripheral blood $B 220^{+} \mathrm{B}$ lymphocytes. Each symbol represents an animal. Values represent mean \pm s.E.M. ${ }^{*} P<0.05, * * P<0.005$, and $* * * P<0.0005$.

evaluated the influence of the in vivo $\mathrm{T}_{3}$-treatment on antigen-specific humoral response to HEL, but no influence was noted (not shown), indicating that the increase in immunoglobulin production under $\mathrm{T}_{3}$ treatment is possibly under immune-regulatory control.

\section{Discussion}

Previous studies have revealed a pleiotropic effect of $T_{3}$ in the immune system. To our knowledge, the present work is the first demonstration that high-circulating levels of $\mathrm{T}_{3}$ can induce B-cell differentiation into plasma cells and their accumulation in the bone marrow.

Published by Bioscientifica Ltd. 

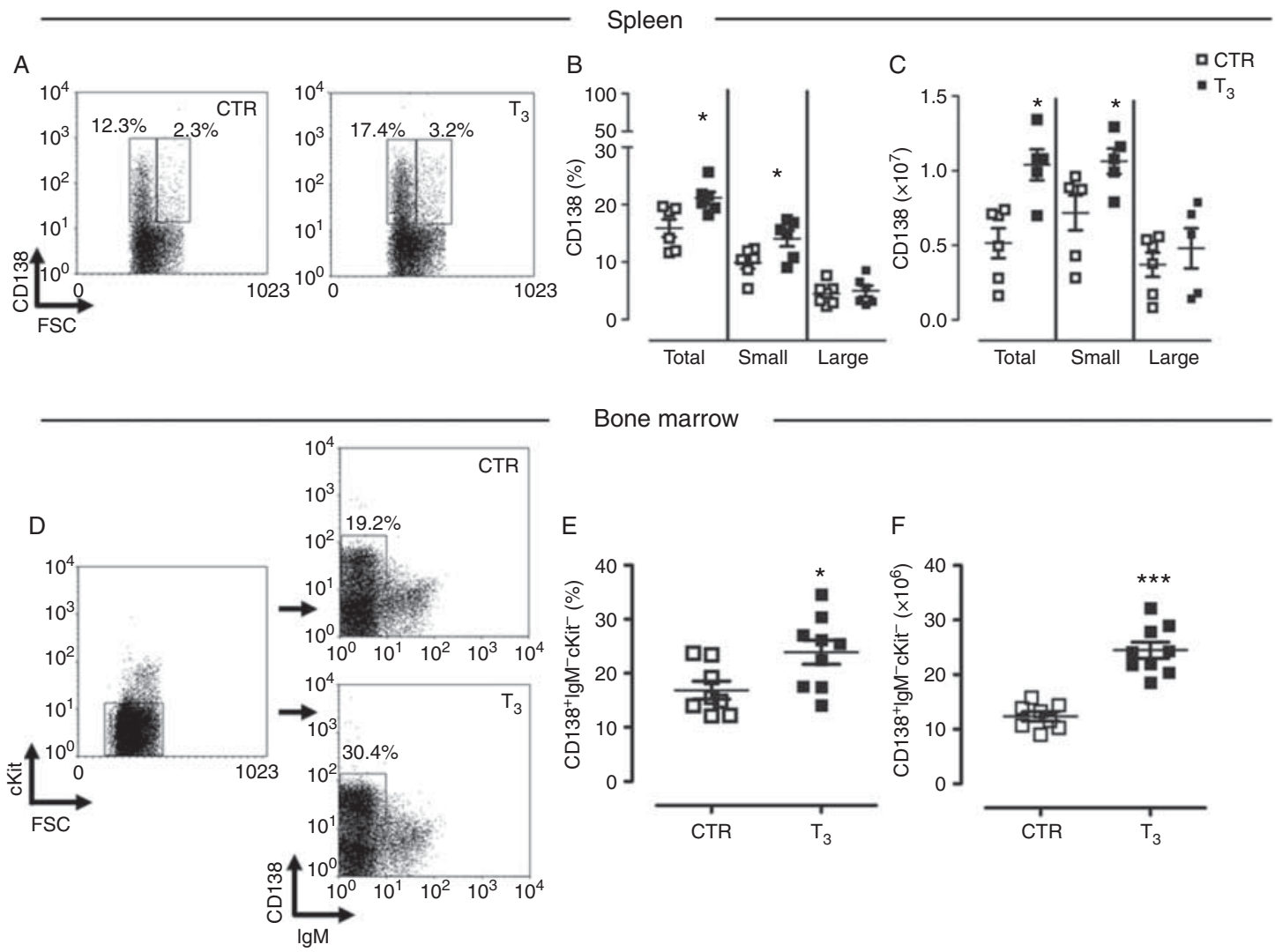

Bone marrow
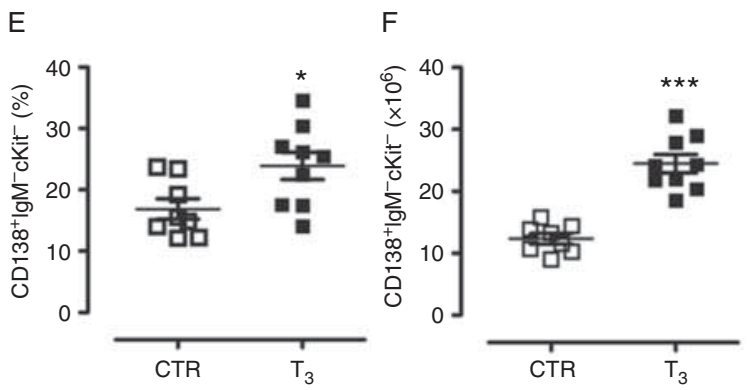

\section{Figure 5}

Increased percentage and number of plasma cells in the spleen and bone marrow of mice with high-circulating levels of $\mathrm{T}_{3}$. Male mice were treated with saline (CTR) or $\mathrm{T}_{3}$ for 14 days. For FACS analyses, cells were isolated from $(A, B$ and $C$ ) spleen or ( $D, E$ and $F$ ) bone marrow and stained with antiCD138-PE or anti-CKit-APC, anti-CD138-PE, and anti-IgM-FITC respectively. (A) Representative CD138-PE vs FSC dot plots gated for the splenic lymphocyte population. (B) Frequencies and (C) absolute numbers of total

In this study, we found that mice with highcirculating levels of $\mathrm{T}_{3}$ showed an increase in the weight of their spleens, in agreement with the results observed by Baldridge \& Peterson (1927) in rats. We also noted that the increase in the spleen weight and cellularity observed in $\mathrm{T}_{3}$-treated mice was, at least in part, due to an increase in the number of splenic B lymphocytes in these animals; however, other cell types may also be affected. In this regard, we previously showed that intrathymic injection of $\mathrm{T}_{3}$ stimulates the output of $\mathrm{T}$-cells to peripheral lymphoid organs in mice (Ribeiro-Carvalho et al. 2007). In addition, Klecha et al. (2005) demonstrated an increase in the mitogen-induced $\mathrm{T}$-cell proliferation in mice previously treated with $\mathrm{T}_{4}$.

Alterations of B-cell numbers in our $\mathrm{T}_{3}$-treated mice were not limited to the spleen, as shown by the enhanced percentage of bone marrow pre-B-cells and immature
$\left(\mathrm{CD} 138^{+}\right)$, small $\left(\mathrm{CD} 138^{+} \mathrm{FSC}^{\mathrm{lo}}\right)$, or large $\left(\mathrm{CD} 138^{+} \mathrm{FSC}^{\mathrm{hi}}\right)$ splenic plasma cells. (D) Dot plots for cKit-APC vs FSC and further analyses based on CD138-PE vs IgM FITC expression in the gate for the bone marrow lymphocyte population indicates bone marrow plasma cells (CD138 $\left.{ }^{+} \mathrm{IgM}^{-} \mathrm{CKit}^{-}\right)$. (E) Frequencies and $(F)$ absolute cell number of bone marrow plasma cells. Each symbol represents an animal. Values represent mean \pm s.E.M. ${ }^{*} P<0.05$ and $* * * P<0.0005$

B-cells. These results corroborated previous studies showing opposite effects on B lymphopoiesis in animal models for hypothyroidism or $T R \alpha$ knockout mice (Foster et al. 1999, Arpin et al. 2000), reinforcing the hypothesis that high-circulating levels of $\mathrm{T}_{3}$ can stimulate bone marrow $\mathrm{B}$ lymphopoiesis.

We observed a decreased percentage of mature B-cells in the bone marrow accompanied by an increased percentage of B-cells in the peripheral blood of mice with high-circulating levels of $\mathrm{T}_{3}$. These results may be due to a stimulatory effect of $\mathrm{T}_{3}$ on the homing of B-cells from the bone marrow to the peripheral lymphoid organs. According to this hypothesis, we found an increase in the percentage and absolute numbers of splenic NF B-cells in mice under the influence of $\mathrm{T}_{3}$. Interestingly, NF B-cells include the transitional 1 B-cell subset (T1), which corresponds to recent B-cell immigrants from the bone 


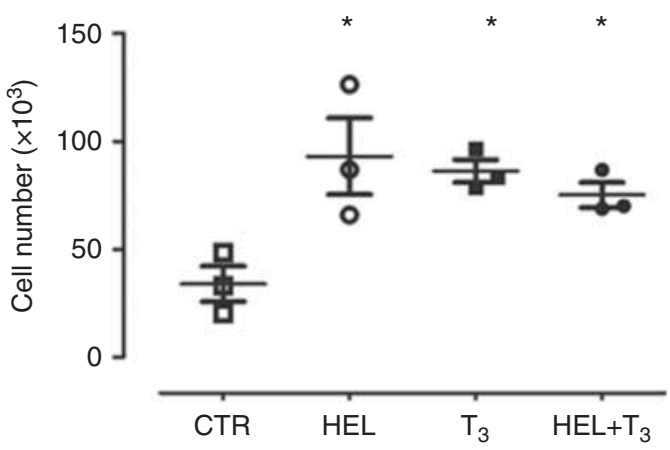

\section{Figure 6}

High-circulating levels of $T_{3}$ promote an increase in the number of immunoglobulin-secreting splenic plasma cells ex vivo. IgM-secreting plasma cell numbers in the spleens isolated from male mice immunized or not with HEL-Alum and subsequently treated or not with $\mathrm{T}_{3}$ for 14 days. Control mice received injections of vehicle solution only. Each symbol represents the number of immunoglobulin-secreting cells in an animal, based on the corresponding number of spots counted, following ELISpot assay, in relation to the total cellularity of the spleen. Values represent mean \pm S.E.M. ${ }^{*} P<0.05$ compared with the control group.

marrow to the spleen (Loder et al. 1999, Hu et al. 2004). Once in the spleen, these cells differentiate into two subsets of mature B-cells, FO, or MZ B-cells, depending on the anatomical region to which they migrate and are positioned in the spleen (Loder et al. 1999, Pillai \& Cariappa 2009). These processes are regulated, at least in part, by extracellular matrix and chemokine molecules (Mebius \& Kraal 2005, Lokmic et al. 2008). In this regard, we have previously shown that mice treated with $\mathrm{T}_{3}$ exhibited modulation of extracellular matrix components in the spleen, increasing the expression of laminin and fibronectin glycoproteins (Ribeiro-Carvalho et al. 2007). However, additional studies are still necessary to verify whether $\mathrm{TH}$ excess regulates B-cell homing by modulating the levels of extracellular matrix molecules and chemokine expression and responsiveness.

We found an increase in the splenic $\mathrm{CD} 19^{+} \mathrm{B}$ lymphocyte population associated with an enhanced frequency and number of bone marrow pre-B-cell progenitors and mature B-cells as well as with the increase in blood B220 ${ }^{+}$ cells and splenic NF B-cells in $\mathrm{T}_{3}$-treated mice. These results support the hypothesis that high-circulating levels of $T_{3}$ stimulate bone marrow B lymphopoiesis. Opposite effects showing a reduction in the percentage of B-cell progenitors were observed in TR $\alpha$-/- mice (Arpin et al. 2000). The authors also showed a decrease in the number of $\mathrm{B} 220^{+}$ cells in TR $\alpha$-/- mice. In our work, we did not observe a significant change in the absolute number of $\mathrm{B}_{2} 2 \mathrm{O}^{+}$cells after treatment with $\mathrm{T}_{3}$. However, we observed a decreased frequency and expression per cell of B220 cells in the spleen, as demonstrated by FACS and geometric mean of fluorescence intensity (gMIF) analyses.

Although we found $\mathrm{B} 220^{+} \mathrm{TCR}^{+} \mathrm{T}$ cells decreased by $2 \%$ in the spleen under the influence of $\mathrm{T}_{3}$, a decrease of almost $10 \%$ in B220 expression was observed in $\mathrm{TCR}^{-} \mathrm{B}_{220^{+}}$cells. In addition, a significant effect of $\mathrm{T}_{3}$ was observed on $\mathrm{B}_{2} 20^{+} \mathrm{GR} 1^{+}$cells, which include the plasmocytoid cell population (Nakano et al. 2001). These results gave support to the hypothesis that the decrease in B220 expression might occur on the B-cell surface, which correlates with the stimulatory effect of excess $T_{3}$ on plasma cell differentiation.

A significant increase in the percentage and number of $\mathrm{CD}_{138^{+}}$plasma cells was observed in the spleens of mice treated with $\mathrm{T}_{3}$. It was possible to define two subpopulations of plasma cells according to their size. We propose that small $\mathrm{CD} 138^{+}$plasma cells, which showed a significant increase under the effect of $\mathrm{T}_{3}$, might correspond to plasmablasts, plasma cells at early stage of differentiation, that have down-modulated B220 but still express CD19 in the cell surface (Radbruch et al. 2006, Mei et al. 2012). In contrast, large $\mathrm{CD} 138^{+}$plasma cells, which might correspond to cells at a later stage of differentiation, showed only a trend to increase in number after $T_{3}$ treatment. Our data also indicated a significant increase in the percentage of plasma cells in the bone marrow of $\mathrm{T}_{3}$-treated mice. Taken together, these effects suggest that excess $T_{3}$ may stimulate generation of splenic plasma cells followed by their migration from the spleen to the bone marrow, where they accumulate, possibly because of the existence of long-lived plasma cell survival niches (Radbruch et al. 2006, Tokoyoda et al. 2010).

Other studies have shown a stimulatory effect of $\mathrm{T}_{3}$ on the synthesis of IL6, which is a potent plasma cell differentiation inducer (Korholz et al. 1992, Jones et al. 1997, Pontikides \& Krassas 2007). Moreover, serum levels of IL6 are increased in hyperthyroid patients (Celik et al. 1995, Pedro et al. 2011). It is thus possible that excess $T_{3}$ could act systemically through circulating cytokines that can induce plasma cell differentiation. It is interesting to speculate that TH may act upon B-cells, both directly and indirectly, in combination with IL6. This question deserves further investigation.

In our experiments, mice treated with $\mathrm{T}_{3}$ have not shown increased levels of IgG in the serum, indicating that plasma cells in $\mathrm{T}_{3}$-treated animals do not undergo immunoglobulin-class switching. In addition, an ELISpot assay using splenocytes isolated from mice treated with $\mathrm{T}_{3}$ alone showed an increase in the number of IgM-secreting plasma cells, in comparison with control

Published by Bioscientifica Ltd. 
mice, and the magnitude of the increase in secreting plasma cells indicates a polyclonal activation. Interestingly, we found that antigen-specific humoral response was not affected in mice immunized with HEL at day 0 of the 14-day treatment with $\mathrm{T}_{3}$. It would also be interesting to evaluate a possible enhanced effect on humoral response in mice immunized with HEL during or after treatment with $\mathrm{T}_{3}$. Although our observation needs to be extended to other experimental conditions and model antigens, these results indicate that the augmentation of immunoglobulin production under $\mathrm{T}_{3}$ treatment cannot be assumed to hold in general to foreign-antigen-specific stimuli, indicating a more complex process. The data are consistent with the notion that B-cell clones involved in the polyclonal activation induced by $\mathrm{T}_{3}$ could be under immune-regulatory control. For instance, previously established plasma cells and those newly originated by antigen immunization may compete for niches and factors. It is interesting to consider whether the intrinsic state of the plasma cells, long-lived vs short-lived, ontogeny, differentiation and T-cell help may alter their response to $T_{3}$, possibly favoring plasma cells normally present under physiological conditions, such as those involved in the production of natural antibodies (Gronwall et al. 2012, Ouchida et al. 2012, Montaudouin et al. 2013). It would be also relevant to investigate the effects of $\mathrm{T}_{3}$ in mouse models of lupus-like autoimmune diseases, characterized by elevated levels of polyclonal autoantibodies (Shlomchik et al. 1987, Chan et al. 1999).

Previously, Paavonen (1982) used human peripheral blood mononuclear cells from euthyroid individuals to evaluate the combinatory effects of $\mathrm{T}_{3}$ plus mitogens on the levels of immunoglobulin secreted in vitro. Although he did not analyze the effects of $\mathrm{T}_{3}$ alone, he found an increase in the levels of IgG, IgA, and IgE in the culture supernatant of human cells treated with $\mathrm{T}_{3}$ plus $\mathrm{T}$ or $\mathrm{B}$ lymphocyte mitogens, as compared with control cultures treated only with mitogens. The combination of T-cellsecreted interleukins with $\mathrm{T}_{3}$-committed plasma cells may explain the presence of immunoglobulin switching.

The animal model used in this study does not aim to mimic Graves' disease but to investigate the specific effects of high-circulating levels of $\mathrm{T}_{3}$ on B-cells. In animal models of Graves' disease, it is difficult to analyze the effects of high-circulating levels of TH on B-cell physiology due to the interference of autoimmune B lymphocyte activity (Ludgate 2000). In our model of $\mathrm{T}_{3}$-injected mice, serum $\mathrm{T}_{3}$ reached values threefold to fourfold higher than euthyroid levels. Only a trend towards decreased levels of TSH was observed in $\mathrm{T}_{3}$-injected mice. The reduced levels of $\mathrm{T}_{4}$ also observed in these mice could be due to the presence of less-bioactive TSH produced in response to the high levels of $\mathrm{T}_{3}$ in circulation (Dahlberg et al. 1987, Persani 1998).

Even though the findings of our studies may not be directly extrapolated to human diseases, it is possible that our results have clinical implications for the understanding of thyrotoxicosis and Graves' disease. An increase of more than threefold to fourfold in the plasma-circulating levels of $\mathrm{T}_{3}$ can be found in several hyperthyroid patients with Graves' disease, one of the most common forms of thyrotoxicosis, or in $\mathrm{T}_{3}$-predominant Graves' disease (Takamatsu et al. 1988), while TH ingestion in humans can raise the levels of circulating $\mathrm{T}_{3}$ more than twofold (Ohye et al. 2005). Therefore, excess $\mathrm{T}_{3}$ resulting from exogenous administration of $\mathrm{T}_{3}$ may be a valid model to study thyrotoxicosis in the absence of autoimmunity.

In conclusion, excess $\mathrm{T}_{3}$ induces B-cell differentiation into plasma cells in vivo and increases the percentage of these cells in the bone marrow, a long-lived plasma cell survival niche. These data bring insights of relevance to the understanding of clinical observations regarding the remission of autoimmunity in patients with Graves' disease associated with the recovery of the euthyroid state, regardless of the type of treatment (Laurberg et al. 2008). Based on our findings, we propose the existence of a possible mechanism of positive feedback in untreated Graves' disease, involving the activities of thyroid follicular cells and autoimmune B-cells, through the $\mathrm{T}_{3}$-enhanced generation of plasma cells secreting autoreactive antibodies. In this context, it is known that antibodies produced against TSH receptor by activated autoimmune B-cells stimulate the thyroid follicular cells and the consequent increase in the circulating levels of $\mathrm{TH}$. In turn, it is possible that high-circulating levels of $\mathrm{TH}$ could act to stimulate the activity of autoimmune plasma cells, thus aggravating the state of Graves' disease in untreated patients. Further studies in autoimmune mouse models and/or human B-cells of autoimmune patients might help to elucidate the answer to this question.

\section{Declaration of interest}

The authors declare that there is no conflict of interest that could be perceived as prejudicing the impartiality of the research reported.

\section{Funding}

This work was partially supported by the National Council of Technological and Scientific Development/CNPq; the Research Support Foundation of the

Published by Bioscientifica Ltd 
State of Rio de Janeiro/FAPERJ, Brazil; and the National Institute on Aging/NIH, USA. F F B received a PhD fellowship from the Coordenação de Aperfeiçoamento de Pessoal de Nível Superior (CAPES), Ministry of Education, Brazil. Current address of Dr Dennis Taub: VA Medical Center, 50 Irving St. NW, Washington, DC 20422, USA.

\section{References}

Allman D, Lindsley RC, DeMuth W, Rudd K, Shinton SA \& Hardy RR 2001 Resolution of three nonproliferative immature splenic B cell subsets reveals multiple selection points during peripheral B cell maturation. Journal of Immunology 167 6834-6840.

Arpin C, Pihlgren M, Fraichard A, Aubert D, Samarut J, Chassande O \& Marvel J 2000 Effects of T3R $\alpha 1$ and T3R $\alpha 2$ gene deletion on T and B lymphocyte development. Journal of Immunology 164 152-160.

Bahn RS, Burch HB, Cooper DS, Garber JR, Greenlee MC, Klein I, Laurberg P, McDougall IR, Montori VM, Rivkees SA et al. 2011 Hyperthyroidism and other causes of thyrotoxicosis: management guidelines of the American Thyroid Association and American Association of Clinical Endocrinologists. Endocrine Practice 17 456-520. (doi:10.4158/EP.17.3.456)

Baldridge CW \& Peterson FR 1927 Splenic enlargement in hyperthyroidism. Journal of the American Medical Association 88 1701-1702. (doi:10.1001/jama.1927.02680480011006)

Bianco AC 2011 Minireview: Cracking the metabolic code for thyroid hormone signaling. Endocrinology 152 3306-3311. (doi:10.1210/ en.2011-1104)

Burrows PD, Stephan RP, Wang YH, Lassoued K, Zhang Z \& Cooper MD 2002 The transient expression of pre-B cell receptors governs B cell development. Seminars in Immunology 14 343-349. (doi:10.1016/ S1044-5323(02)00067-2)

Celik I, Akalin S \& Erbas T 1995 Serum levels of interleukin 6 and tumor necrosis factor- $\alpha$ in hyperthyroid patients before and after propylthiouracil treatment. European Journal of Endocrinology 132 668-672. (doi:10.1530/eje.0.1320668)

Chan OT, Madaio MP \& Shlomchik MJ 1999 B cells are required for lupus nephritis in the polygenic, Fas-intact MRL model of systemic autoimmunity. Journal of Immunology 163 3592-3596.

Dahlberg PA, Petrick PA, Nissim M, Menezes-Ferreira MM \& Weintraub BD 1987 Intrinsic bioactivity of thyrotropin in human serum is inversely correlated with thyroid hormone concentrations. Application of a new bioassay using the FRTL-5 rat thyroid cell strain. Journal of Clinical Investigation 79 1388-1394. (doi:10.1172/JCI112966)

De Vito P, Incerpi S, Pedersen JZ, Luly P, Davis FB \& Davis PJ 2011 Thyroid hormones as modulators of immune activities at the cellular level. Thyroid 21 879-890. (doi:10.1089/thy.2010.0429)

Fabris N 1973 Immunodepression in thyroid-deprived animals. Clinical and Experimental Immunology 15 601-611.

Fairfax KA, Kallies A, Nutt SL \& Tarlinton DM 2008 Plasma cell development: from B-cell subsets to long-term survival niches. Seminars in Immunology 20 49-58. (doi:10.1016/j.smim.2007.12.002)

Foster MP, Montecino-Rodriguez E \& Dorshkind K 1999 Proliferation of bone marrow pro-B cells is dependent on stimulation by the pituitary/thyroid axis. Journal of Immunology 163 5883-5890.

Gronwall C, Vas J \& Silverman GJ 2012 Protective roles of natural IgM antibodies. Frontiers in Immunology 3 66. (doi:10.3389/fimmu.2012. 00066)

Hardy RR \& Hayakawa K 2001 B cell development pathways. Annual Review of Immunology 19 595-621. (doi:10.1146/annurev.immunol.19.1.595)

Hardy RR, Carmack CE, Shinton SA, Kemp JD \& Hayakawa K 1991 Resolution and characterization of pro-B and pre-pro-B cell stages in normal mouse bone marrow. Journal of Experimental Medicine $\mathbf{1 7 3}$ 1213-1225. (doi:10.1084/jem.173.5.1213)

Hastings ML, Milcarek C, Martincic K, Peterson ML \& Munroe SH 1997 Expression of the thyroid hormone receptor gene, erbA $\alpha$, in $\mathrm{B}$ lymphocytes: alternative mRNA processing is independent of differentiation but correlates with antisense RNA levels. Nucleic Acids Research 25 4296-4300. (doi:10.1093/nar/25.21.4296)

Hou X, Li Y, Li J, Wang W, Fan C, Wang H, Zhang H, Shan Z \& Teng W 2011 Development of thyroid dysfunction and autoantibodies in Graves' multiplex families: an eight-year follow-up study in Chinese Han pedigrees. Thyroid 21 1353-1358. (doi:10.1089/thy.2011.0035)

Hu L, Dixit VD, de Mello-Coelho V \& Taub DD 2004 Age-associated alterations in CXCL1 chemokine expression by murine B cells. BMC Immunology 5 15. (doi:10.1186/1471-2172-5-15)

Ioos V, Das V, Maury E, Baudel JL, Guechot J, Guidet B \& Offenstadt G 2008 A thyrotoxicosis outbreak due to dietary pills in Paris. Therapeutics and Clinical Risk Management 4 1375-1379.

Jones TH, Kennedy RL, Justice SK \& Davies R 1997 Effect of glucocorticoids and oestrogen on interleukin- 6 production by human thyrocytes from patients with Graves' disease and toxic multinodular goitre and from HTori3 cells. European Journal of Endocrinology 137 429-432. (doi:10.1530/eje.0.1370429)

Justement LB 2001 The role of the protein tyrosine phosphatase CD45 in regulation of B lymphocyte activation. International Reviews of Immunology 20 713-738. (doi:10.3109/08830180109045587)

Kallies A, Hasbold J, Tarlinton DM, Dietrich W, Corcoran LM, Hodgkin PD \& Nutt SL 2004 Plasma cell ontogeny defined by quantitative changes in Blimp-1 expression. Journal of Experimental Medicine 200 967-977. (doi:10.1084/jem.20040973)

Klecha AJ, Barreiro Arcos ML, Genaro AM, Gorelik G, Silberman DM, Caro R \& Cremaschi GA 2005 Different mitogen-mediated $\beta$-adrenergic receptor modulation in murine $\mathrm{T}$ lymphocytes depending on the thyroid status. Neuroimmunomodulation 12 92-99. (doi:10.1159/ 000083581)

Klecha AJ, Genaro AM, Gorelik G, Barreiro Arcos ML, Silberman DM, Schuman M, Garcia SI, Pirola C \& Cremaschi GA 2006 Integrative study of hypothalamus-pituitary-thyroid-immune system interaction: thyroid hormone-mediated modulation of lymphocyte activity through the protein kinase C signaling pathway. Journal of Endocrinology 189 45-55. (doi:10.1677/joe.1.06137)

Klein U \& Dalla-Favera R 2007 Unexpected steps in plasma-cell differentiation. Immunity 26 543-544. (doi:10.1016/j.immuni. 2007.05.005)

Korholz D, Gerdau S, Enczmann J, Zessack N \& Burdach S 1992 Interleukin 6-induced differentiation of a human B cell line into IgM-secreting plasma cells is mediated by c-fos. European Journal of Immunology $\mathbf{2 2}$ 607-610. (doi:10.1002/eji.1830220248)

Laurberg P, Wallin G, Tallstedt L, Abraham-Nordling M, Lundell G \& Torring O 2008 TSH-receptor autoimmunity in Graves' disease after therapy with anti-thyroid drugs, surgery, or radioiodine: a 5-year prospective randomized study. European Journal of Endocrinology $\mathbf{1 5 8}$ 69-75. (doi:10.1530/EJE-07-0450)

Loder F, Mutschler B, Ray RJ, Paige CJ, Sideras P, Torres R, Lamers MC \& Carsetti R 1999 B cell development in the spleen takes place in discrete steps and is determined by the quality of B cell receptor-derived signals. Journal of Experimental Medicine 190 75-89. (doi:10.1084/jem.190.1.75)

Lokmic Z, Lammermann T, Sixt M, Cardell S, Hallmann R \& Sorokin L 2008 The extracellular matrix of the spleen as a potential organizer of immune cell compartments. Seminars in Immunology 20 4-13. (doi:10.1016/j.smim.2007.12.009)

Ludgate M 2000 Animal models of Graves' disease. European Journal of Endocrinology 142 1-8. (doi:10.1530/eje.0.1420001)

Mebius RE \& Kraal G 2005 Structure and function of the spleen. Nature Reviews. Immunology 5 606-616. (doi:10.1038/nri1669)

Mei HE, Schmidt S \& Dorner T 2012 Rationale of anti-CD19 immunotherapy: an option to target autoreactive plasma cells in autoimmunity. Arthritis Research \& Therapy 14(Suppl 5) S1. (doi:10.1186/ar3909)

Montaudouin C, Anson M, Hao Y, Duncker SV, Fernandez T, Gaudin E, Ehrenstein M, Kerr WG, Colle JH, Bruhns P et al. 2013 Quorum sensing 
contributes to activated IgM-secreting B cell homeostasis. Journal of Immunology 190 106-114. (doi:10.4049/jimmunol.1200907)

Montecino-Rodriguez E, Leathers H \& Dorshkind K 2006 Identification of a B-1 B cell-specified progenitor. Nature Immunology 7 293-301. (doi:10.1038/ni1301)

Nakano H, Yanagita M \& Gunn MD 2001 CD11c ${ }^{+}$B220 ${ }^{+}$Gr- $1^{+}$cells in mouse lymph nodes and spleen display characteristics of plasmacytoid dendritic cells. Journal of Experimental Medicine 194 1171-1178. (doi:10.1084/jem.194.8.1171)

Nijnik A, Pistolic J, Wyatt A, Tam S \& Hancock RE 2009 Human cathelicidin peptide LL-37 modulates the effects of IFN- $\gamma$ on APCs. Journal of Immunology 183 5788-5798. (doi:10.4049/jimmunol.0901491)

Ohye H, Fukata S, Kanoh M, Kubota S, Kuma K, Miyauchi A \& Sugawara M 2005 Thyrotoxicosis caused by weight-reducing herbal medicines. Archives of Internal Medicine 165 831-834. (doi:10.1001/archinte. 165.8.831)

Oliveira KJ, Ortiga-Carvalho TM, Cabanelas A, Veiga MA, Aoki K, OhkiHamazaki H, Wada K, Wada E \& Pazos-Moura CC 2006 Disruption of neuromedin $\mathrm{B}$ receptor gene results in dysregulation of the pituitarythyroid axis. Journal of Molecular Endocrinology 36 73-80. (doi:10.1677/ jme.1.01892)

Ouchida R, Mori H, Hase K, Takatsu H, Kurosaki T, Tokuhisa T, Ohno H \& Wang JY 2012 Critical role of the IgM Fc receptor in IgM homeostasis, B-cell survival, and humoral immune responses. PNAS 109 E2699-E2706. (doi:10.1073/pnas.1210706109)

Paavonen T 1982 Enhancement of human B lymphocyte differentiation in vitro by thyroid hormone. Scandinavian Journal of Immunology $\mathbf{1 5}$ 211-215. (doi:10.1111/j.1365-3083.1982.tb00640.x)

Pedro AB, Romaldini JH \& Takei K 2011 Changes of serum cytokines in hyperthyroid Graves' disease patients at diagnosis and during methimazole treatment. Neuroimmunomodulation 18 45-51. (doi:10.1159/000311519)

Persani L 1998 Hypothalamic thyrotropin-releasing hormone and thyrotropin biological activity. Thyroid 8 941-946. (doi:10.1089/ thy.1998.8.941)

Pillai S \& Cariappa A 2009 The follicular versus marginal zone B lymphocyte cell fate decision. Nature Reviews. Immunology 9 767-777. (doi:10.1038/nri2656)

Pontikides N \& Krassas GE 2007 Basic endocrine products of adipose tissue in states of thyroid dysfunction. Thyroid 17 421-431. (doi:10.1089/ thy.2007.0016)
Radbruch A, Muehlinghaus G, Luger EO, Inamine A, Smith KG, Dorner T \& Hiepe F 2006 Competence and competition: the challenge of becoming a long-lived plasma cell. Nature Reviews. Immunology 6 741-750. (doi:10.1038/nri1886)

Renno T, Attinger A, Rimoldi D, Hahne M, Tschopp J \& MacDonald HR 1998 Expression of B220 on activated T cell blasts precedes apoptosis. European Journal of Immunology 28 540-547. (doi:10.1002/(SICI) 1521-4141(199802)28:02 <540::AID-IMMU540>3.0.CO;2-Y)

Ribeiro-Carvalho MM, Smaniotto S, Neves-dos-Santos S, Mouco T, Savino W \& Mello-Coelho V 2007 Triiodothyronine modulates differential homing of recent thymic emigrants to peripheral lymphoid organs. Scandinavian Journal of Immunology 66 8-16. (doi:10.1111/j.1365-3083.2007.01910.x)

Shahrara S, Drvota V \& Sylven C 1999 Organ specific expression of thyroid hormone receptor mRNA and protein in different human tissues. Biological \& Pharmaceutical Bulletin 22 1027-1033. (doi:10.1248/ bpb.22.1027)

Shlomchik MJ, Marshak-Rothstein A, Wolfowicz CB, Rothstein TL \& Weigert MG 1987 The role of clonal selection and somatic mutation in autoimmunity. Nature 328 805-811. (doi:10.1038/328805a0)

Su YW, Hao Z, Hirao A, Yamamoto K, Lin WJ, Young A, Duncan GS, Yoshida H, Wakeham A, Lang PA et al. 2011 14-3-3 $\sigma$ regulates B-cell homeostasis through stabilization of FOXO1. PNAS 108 1555-1560. (doi:10.1073/pnas.1017729108)

Takamatsu J, Hosoya T, Naito N, Yoshimura H, Kohno Y, Tarutani O, Kuma K, Sakane S, Takeda K \& Mozai T 1988 Enhanced thyroid iodine metabolism in patients with triiodothyronine-predominant Graves' disease. Journal of Clinical Endocrinology and Metabolism $6 \mathbf{6}$ 147-152. (doi:10.1210/jcem-66-1-147)

Tokoyoda K, Hauser AE, Nakayama T \& Radbruch A 2010 Organization of immunological memory by bone marrow stroma. Nature Reviews. Immunology 10 193-200. (doi:10.1038/nri2727)

Ueki I, Abiru N, Kobayashi M, Nakahara M, Ichikawa T, Eguchi K \& Nagayama Y 2011 B cell-targeted therapy with anti-CD20 monoclonal antibody in a mouse model of Graves' hyperthyroidism. Clinical and Experimental Immunology 163 309-317. (doi:10.1111/j.1365-2249. 2010.04301.x)

Walfish PG 1976 Triiodothyronine and thyroxine interrelationships in health and disease. Canadian Medical Association Journal 115 338-342.

Ye M \& Graf T 2007 Early decisions in lymphoid development. Current Opinion in Immunology 19 123-128. (doi:10.1016/j.coi.2007.02.007)

Received in final form 15 December 2013

Accepted 19 December 2013

Accepted Preprint published online 20 December 2013
(C) 2014 Society for Endocrinology Printed in Great Britain
Published by Bioscientifica Ltd. 